\title{
Coping with Difficulties in Parenting Situations - Parental Control, Obedience Enforcement and Directiveness
}

\author{
Agnieszka Szymańska \\ Uniwersytet Kardynala Stefana Wyszynskiego
}

\begin{abstract}
One's proper reaction to difficulties is seen as an important factor of parental abilities. This research study verifies whether parents of either "badly-behaved" or "well-behaved" children vary in their reactions to difficult parenting situations connected with their relationship with their child. The group of "badly-behaved" children had externalizing and internalizing problem behaviors. The "well-behaved" children's group consisted of extraordinarily mature and properly behaved children according to their kindergarten teachers. The research sample consisted of 204 parents of "badly-behaved" and "well-behaved" children. The research was conducted in Poland. The DAiS scale was used to assess the level and type of parental directiveness, and the PAiNK scale was used to assess obedience enforcement and teaching the rules of proper behavior. Multiple regression, the Sobel test and partial correlation were used to identify mediation effects. The results show that the two groups differ in their reactions to difficulties: a) the parents of "well-behaved" children emphasize the teaching of rules, and this effect is stronger in older children, b) the parents of "badly-behaved" children use aggressive directiveness. This effect is stronger when the children approach school age.
\end{abstract}

Key words: difficult parenting situations, parent-child relationship, parental control, directiveness, obedience enforcement

\section{Introduction}

This paper presents the results of research on how parents cope with difficulties they experience in parenting situations. These are subsequent studies in a series of studies on the influence parents have on their children (Szymańska, 2009a, 2008b, 2012a, 2011; Szymańska, 2015). In these studies, the parents' ways of coping with difficulties are limited to such behaviors as: directiveness, obedience enforcement, and teaching the child rules of proper

Correspondence concerning this article should be addressed to Agnieszka Szymańska, Instytut Psychologii, Uniwersytet Kardynała Stefana Wyszyńskiego, ul. Wóycickiego $1 / 3$ bud. 14|01938 Warszawa. E-mail: elysium5678@gmail.com

Received July 30, 2015 behavior (Parental Control). These are behaviors from the circle of parental influence, yet parents can use much more diverse behaviors when faced with experienced difficulties, such as seeking the assistance of a psychologist, that of the child's grandparents, etc.

The ways parents cope with the difficulties that were selected for this study can be justified in the literature. They have long been of interest regarding the connection between experienced difficulties and parents' influences (Bugental \& Happaney, 2000). Parents' reactions to a given parenting difficulty have been the subject of many studies. Researchers measured the influence of parenting difficulties on the use of aggressive and authoritarian behaviors towards the child (Bugental \& Happaney, 2000), and teachers' and parents' attitudes towards 'difficult' children (Bugental \& Shennum, 1984; Czwartosz, 1989; Porębska, 1982). An experi- 
enced parenting difficulty is also distinguished as one of the reasons for mistakes that are made by parents (Gurycka, 1990).

Moreover, the results concerning parental influences, such as parental control, directiveness and the parents' communication style with the child have extensively been analyzed worldwide (Baumrind, 1983; Baumrind \& Black, 1967; Baumrind, 1966; Bugental \& Shennum, 1984; Goodman, Bartfoot, Frye, \& Belli, 1999; Perkins Quamma \& Greenberg, 1994; Stewart \& Rubin, 1995; Del Vecchio \& O’Leary, 2008). The results of these studies have led to contradictory conclusions. According to a study by Pettit and colleagues (Pettit, Dodge, \& Brown, 1988) and the research of Krasno and Rubin (Krasno \& Rubin, 1983), parents' directiveness is not related to their children's social competence. In contrast, the results of Rose-Krasnor and colleagues (Rose-Krasnor, Rubin, Booth, \& Coplan, 1996) showed that the directiveness of parents is associated with the social behavior of their children. Studies by Carlson-Jones and colleagues (Carlson-Jones, Rickel, \& Smith, 1980) showed, however, that the directive behaviors of mothers are associated with the aggressive behaviors of their children. This discrepancy results from the different definitions of directiveness in either European, American, and Australian culture (Ray \& Lovejoy, 1988; Szymańska, 2008a). These differences will be shown in this article.

So far, studies have revealed that there are significant differences in how these influences are applied in the Polish group of mothers and fathers of "well-behaved" and "badly-behaved" children (Szymańska, 2009c, 2009b). The "badlybehaved" children are a group of children who have externalizing and internalizing problem behaviors. Children with internalizing problem behaviors are shy, sad, withdrawn, experience difficulty in concentration, etc. Children with externalizing problem behaviors refuse to follow the rules, are destructive and aggressive towards other children, and behave impulsively. The "well-behaved" children behave extraordinarily well according to their kindergarten teacher. They have no problem behavior.

The analysis revealed the interaction effect between the gender of the parent and the child's behavior when demanding obedience from that child. In the group of parentsof "well-behaved" children, the fathers demanded that their children comply with their orders. In the group of parents of "badly-behaved" children this was the opposite, i.e. "discipline in the home" was required by the mothers (Szymańska, 2009c).

The study also showed very large differences in the usage of directiveness in the groups of mothers and fathers of "well-behaved" and "badly-behaved" children, e.g. the parents of the "badly-behaved" children used more Aggressive Directiveness and the parents of the "well-behaved" children used more Warmhearted Directiveness.

The mothers of the "well-behaved" children most often applied Warm-hearted Directiveness and, at the same time, Aggressive Directiveness the least. The fathers of the "well-behaved" children applied Warm-hearted Directiveness less often than their wives but significantly more often than the mothers and fathers of "badlybehaved" children. They also applied Aggressive Directiveness more often than their wives but significantly less often than the parents of "badly-behaved" children.

The mothers of the "badly-behaved" children used Warm-hearted Directiveness less often than the parents of "well-behaved" children but more often than their husbands. They also used Aggressive Directiveness more often than the parents of "well-behaved" children. The fathers of the "badly-behaved" children used Warmhearted Directiveness the least often among all of the groups and Aggressive Directiveness the most often among all of the groups (Szymańska, 2009b). 
Still other studies showed that the groups of parents of "well-behaved" and "badly-behaved" children differed primarily in their usage ofWarm-hearted Directiveness, then in Aggressive Directiveness, subsequently in demanding obedience from the child, and, finally, in using parental control (Szymańska, 2012b).

Earlier analyses have focused on the differences between groups of parents. The analysis presented here focuses on explaining how the parents of "well-behaved" and "badly-behaved" children react in the face of the difficulties they experience in their relationship with their child, i.e. how do they differ in their reactions? It is known that the parents of "wellbehaved" children apply more Warm-hearted Directiveness than the parents of "badly-behaved" children. Do they also apply Warmhearted Directiveness when they experience difficulties? And when they are experiencing a difficulty do they reinforce parental control or rather demand obedience from the child?

Answering these questions was the main objective of these analyses. In this study the following control variables were taken into account: a) the child's gender, b) child's age, and c) the child's birth order in the family. This was justified by the fact that parental influences may be different depending on the characteristics of the child. It can be expected that with younger children, usage of control and directiveness may have a different character. These influences may also differ with regard to the child's birth order in the family. There are many studies revealing that parents treat younger and older children differently (Praszkier, 1992). The aim of this study was to verify these issues.

It is known that a parent's reaction to a difficulty depends on many factors, such as the parent's character, and affects the behavior of the child. It shapes the parent-child relationship (Gurycka, 1990); the child's behavior and his/her features, e.g. his/her temperament, also affect the parent. The child's temperament can be a variable which moderates many parental behaviors (Casanueva et al., 2010; Lee, 2013; Puura et al., 2013; Phillips, Crowell, Sussman, Fox, \& Hane, 2012; Kochanska \& Kim, 2013). It may also determine the way in which parents experience interactions with the child. It may especially determine the level of stress as experienced by parents and parental welfare in general (Bruning \& Mcmahon, 2009; Casalin, Tang, Vliegen, \& Luyten, 2014; Laukkanen \& Ojansuu, 2014; Mclean, 2012; Oddi, Murdock, \& Vadnais, 2013).

The study sought to answer the following question: how do parents behave in the face of experienced difficulties. We looked for differences in groups of children whose preschool teachers classified them as "badly-behaved" and those who were classified as "well-behaved". However, the choice of groups should not be interpreted as a suggestion that the parent's behavior caused the difference in the children's behavior (i.e., of being either well- or badly behaved). The fact is that children are different temperamentally and some of them may be more difficult from the start than others. This does not have to be conditioned by the behavior of their parent(s).

\section{Difficulty in Parenting Situations}

Research on difficulties experienced by parents in their relationship with their child has been the focus of many studies (Bugental \& Shennum, 1984; Czwartosz, 1989; Porębska, 1982; Kowalik, 2011; Szymańska, 2012a). Difficulty itself is defined as 'the condition or fact of being difficult, something that is difficult as a hard problem or an obstacle or objection, trouble, distress, a disagreement or quarrel. Difficulty is applied to anything hard to contend with, without restriction as to nature, intensity, etc.' (Guralnik, 1986).

In psychological terms, difficulty is synonymous with the notion of mental stress and re- 
fers to all difficult situations which the person has to deal with (Reykowski, 1966); hence the statements "coping with stress" and "coping with difficulties" are synonymous. The notion of "parental difficulty" or "difficulty in parenting situations" narrows down the scope of this notion to situations relating to upbringing the child and interactions with the child. By stating that a parent experiences difficulty we mean that he/she experiences stress in the parental situation.

The causes of parental difficulty are observed in several sources: according to Gurycka, this is in the parent's inability to achieve objectives (Gurycka, 1990), according to Bugental it is in the lack of competences (Bugental \& Happaney, 2000), according to other theories it lies in the difficult behaviors of a child (Porębska, 1982) or in the child's clinical disorders (Kowalik, 2011) and in the child's temperamental characteristics (Buss \& Plomin, 1984). This is shown in Figure 1.

According to Gurycka, the consequence of a parent's experienced difficulties is the formation of a representation of the child in the mind of that parent (Gurycka, 1990) (Figure 1). This thinking is based on concepts of stress which state that stress forms a representation of the object that has caused the stress (Reykowski, 1966). Contemporary theories of stress describe this in a similar manner (Lazarus, DeLongis, Folkman, \& Gruen, 1985).

The parent can exhibit different behaviors depending on the representation of the child in that parent's mind. This is also confirmed by theories of coping with stress (Reykowski, 1966; Lazarus et al., 1985).

Difficult situations, e.g. stress, are considered to be dangerous as in some theories (Gurycka's and Korczak's theory) they are believed to be the cause of parental mistakes (Gurycka, 2008). Korczak drew attention to the relationship between experienced difficulties (stress) and mistakes educators make; he wrote: "in this being lost you can easily become a tyrant if you do not realize that when you act in difficult situations you can make a mistake, an unrecoverable mistake" (Korczak, 1992).

These concepts encourage one to analyze difficult situations, to observe how parents behave in difficult situations and how they exert influence on their children. The theories of stress and coping with difficulties emphasize that the ways of coping with stress may de-

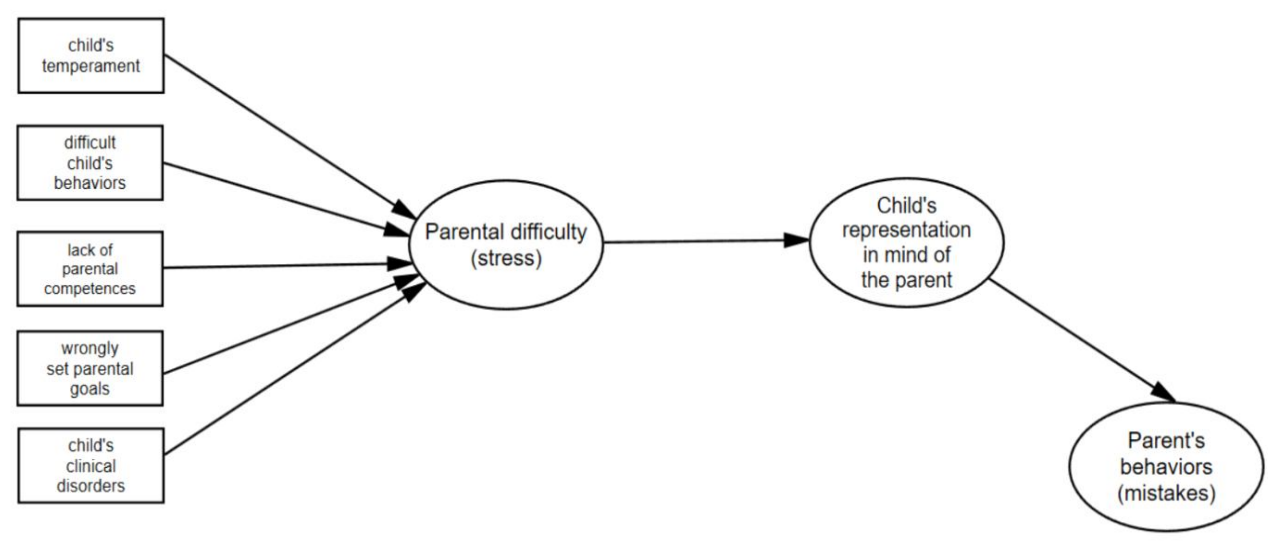

Figure 1 Graphic representation of the causes and effects of experienced parental difficulties 
pend on a person's ability to cope with a difficult situation.

\section{Coping with Difficulties}

The styles of coping with difficulties differ among people. Based on the theories of coping with stress, it can be predicted that there are at least two ways in which parents may cope with difficulties: the first is to flee from the parenting situation and the second is to fight the difficulties (Gurycka, 1979; Kruk, 2005; Katz \& Gottman, 1993; Selye, 1956; Reykowski, 1966).

The reaction of fleeing can be both adaptive and maladaptive. The adaptive reaction might be seeking help, and the maladaptive one might be withdrawal from the situation and doing nothing (Table 1) (Reykowski, 1966).

In the case of withdrawal from the situation, a parent may try to avoid contact with the child and may not take care of him. When seeking help the parent may consult more experienced individuals, e.g. a psychologist, the child's grandparents, etc. The reactions of fighting the difficulties (these can also be adaptive or maladaptive) are as follows: adaptive might be cognitive distancing and maladaptive might be applying pressure (Reykowski, 1966) (Table 1).

Cognitive distancing is a calm considering of the situation and making attempts to alter it in order to solve the problem. In such a situation the parent can, e.g. try to understand what caused the difficulty in the relationship with the child and try to solve it by talking with the child, using explanations, etc.

Applying pressure involves forcing someone to change the situation. Such behaviors on behalf of the parent include trying to force the child, to subordinate the child to the parent's commands, or using violence to force submission on the child. The way that parents react to difficulties may depend on their personality.

Mature and strongly motivated people solve difficulties in adaptive rather than maladaptive ways, but whether people choose adaptive or maladaptive ways depends on their personality, self-esteem and ability to cope with difficulties in a given situation (Ebstrup, Eplov, Pisinger, \& Jørgensen, 2011; Gaudreau, Carraro, \& Miranda, 2012; Reeve, 2005; Reykowski, 1966).

Bugental proved that parents who have a low sense of parental abilities use more verbal aggressive behaviors toward the child and humiliate that child (we could say that they use the maladaptive method of combating difficulties). On the contrary, parents who have high parental abilities do not use methods of exerting influence which would humiliate the child (Bugental \& Happaney, 2000).

One of the methods used by parents in difficult situations might be Warm-hearted Directiveness, i.e. when a parent tries to influence the child via conversations, giving directions and explanations (cognitive distancing, adaptive method of combating difficulties) (Szymańska, 2015). Another method is exerting control, which might manifest itself in teaching the rules of proper behavior (parental control, cognitive distancing, adaptive method of combating difficulties) or in enforcing obedience when the parent compels the child to obey his/ her orders (pressure, maladaptive method of combating difficulties) (Szymańska, 2012b). The parent may behave indifferently or lose his/her temper and behave aggressively towards the child (pressure, method of combating difficul-

Table 1 Four categories of stress response

\begin{tabular}{lll}
\hline & adaptive & maladaptive \\
\hline fight & cognitive distancing & pressure \\
flee & help seeking & withdrawal \\
\hline
\end{tabular}


ties). All four possible parental behaviors representing adaptive and maladaptive methods of combating difficulties were measured in the research presented here.

When a parent experiences difficulties in his/ her relationship with the child (depending on his/her abilities of coping with difficulties and reducing their level as well as finding the possible outcomes of difficult situations), he/she may adopt different ways of coping with the difficulties. On a theoretical basis it was expected that experiencing difficulties might determine changes in: a) the communication style with a child - there might be more aggressive remarks towards the child, $b$ ) the level of teaching the child rules of proper behavior, or c) the level of enforcing obedience.

Such parental behaviors might be intended to restore the parental sense of influence as well as to exert influence on the child in order to change his/her behavior, e.g. via shouting to stop the child's current action.

It seems that parents may differ in their reactions to difficulties. Depending on the parent's ability to cope with difficult situations the parent may affect his/her child properly or improperly. Children also learn how to cope with difficulties from their interaction with their parents. Children whose parents adopt aggressive behaviors may also adopt similar aggressive behaviors in their interactions with their peers. On the contrary, parents who adopt proper and calm reactions to difficulties teach their children how to cope with difficulties in a composed way.

\section{Method}

\section{Aims of the Present Studies and Hypothesis}

In the present study an attempt was made to verify assumptions about the relationship between difficulties experienced by parents and the influence that parents exert on their chil- dren. The aim of this study was to answer the question whether differences exist in groups stratified according to the child's behavior in preschool (classified as either "well-behaved" or "badly-behaved" in the teacher's opinion) and, if so, how the parents in these groups differ in their coping with difficulties in parenting situations.

The general hypothesis of the research was: $\mathrm{H}$ : The parents of "well-behaved" and "badlybehaved" children differ in their methods of combating difficulties when experiencing a difficulty. Study Plan

The study was correlational. The status variables were as follows:

Independent Variables:

Child's order. Variable referred to the child's birth order in the family.

Child's age. Variable was measured in years of life.

Education level. Variable referred to the number of years of the parent's education.

Difficulty experienced in the relationship with the child. Information about the parent-child relationship and the level of parental difficulties experienced in this relationship was gathered by posing the question: "How would you assess your relationship with your child?" Parents answered on a 5-point scale ( $5=$ extraordinary difficulties, $1=$ child behaves very well).

\section{Dependent Variables.}

Warm-hearted Directiveness measures acts of speech, such as commands, requests, or directions, given to a child in a polite manner.

Aggressive Directiveness measures acts of speech, such as commands, requests, or directions, given to a child in an aggressive manner.

Enforcing Obedience measures the requirement that the child immediately obey the parent's orders.

Parental Control measures parental control expressed by teaching the child the principles of correct behavior (teaching rules) in different situations, e.g. social. 


\section{Participants and Procedure}

The research was conducted in three Polish cities: Warsaw, Cracow and Czestochowa. In order to deduce the children's social abilities and behavior, preschool teachers were asked to identify three of the most "badly-behaved" (difficult) and three extraordinarily "well-behaved" children in their groups. Thus two groups of children were gathered. The parents of the selected children were then asked to take part in the research. A total of 204 parents of 4- to 6-year-old children took part: 102 mothers and 102 fathers. The parents completed the questionnaires at home.
There was a similar number of boys and girls in each group. The girls, however, were classified rather as well-behaved and the boys as badly-behaved (Table 2). The birth order of the children in the family was very similar in the group of "well-behaved" and "badly-behaved" children. The group of middle children was the least represented (Table 3).

The age distribution of the children across age groups varied. Younger children (4 years old) predominated in the group of "well-behaved" children; the group of "badly-behaved" children mainly consisted of 5-year-old children (Table 4). The relationship between the teacher's opinion regarding the behavior of the child in preschool and the difficulty experienced by the

Table 2 Number of boys and girls in the sample

\begin{tabular}{llcc}
\hline Teacher's opinion & Child's gender & Number & Percent \\
\hline \multirow{2}{*}{ well-behaved } & girls & 62 & 60.8 \\
& boys & 40 & 39.2 \\
badly-behaved & girls & 35 & 34.3 \\
& boys & 66 & 64.7 \\
\hline
\end{tabular}

Table 3 Birth order of the child in the family

\begin{tabular}{llll}
\hline Teacher's opinion & Child's order & Number & Percent \\
\hline \multirow{3}{*}{ well-behaved } & oldest & 66 & 64.7 \\
& middle & 6 & 5.9 \\
& youngest & 30 & 29.4 \\
\hline \multirow{3}{*}{ badly-behaved } & oldest & 63 & 61.8 \\
& middle & 3 & 2.9 \\
& youngest & 36 & 35.3 \\
\hline
\end{tabular}

Table 4 Children's age

\begin{tabular}{llcc}
\hline Teacher's opinion & Child's order & Number & Percent \\
\hline \multirow{3}{*}{ well-behaved } & 6 year old & 22 & 21.6 \\
& 5 year old & 30 & 29.4 \\
& 4 year old & 50 & 49 \\
\hline \multirow{3}{*}{ badly-behaved } & 6 year old & 25 & 24.5 \\
& 5 year old & 43 & 42.2 \\
& 4 year old & 34 & 33.3 \\
\hline
\end{tabular}


parent was moderate: 0.388 (Tau-Kendall correlation), $p<0.005$. This explained $15 \%$ variability of the results. It can be stated that the parents shared the opinions of the teachers at a rather small (moderate) level.

\section{Measurement Tools}

The study used two tools that the parents filled out at home: a) a tool to measure directiveness, b) a tool to measure parental control.

DAiS scale for directiveness measurement. The scale was designed to assess both the level and type of parental directiveness (aggressive or warm-hearted). Directiveness is conceptualized as an "act of speech, by which a speaker wants to coax a listener to do something, for example: "close the door, please" (Reber \& Reber, 2005).

Searle (1983) distinguished directives as one of the five acts of speech with which people communicate with each other. According to these definitions, even a normal question such as "What time is it?" is directive speech by means of which the speaker coaxes the listener into doing something. It could be stated that directiveness is a style of exerting influence over others. The opposite of directiveness is nondirectiveness, which can be described as the avoidance of exerting influence.

The scale distinguishes five dimensions of exerting influence over a child. These are: conversation, giving orders, asking for and giving help, and providing correction.

Two types of directiveness have been distinguished, i.e. Warm-hearted Directiveness and Aggressive Directiveness. Warm-hearted Directiveness is a way of exerting influence that is characterized by a positive attitude towards others and avoids repulsing and humiliating them. An example is: 'When the child is doing something wrong, I try to change this by patiently explaining why; I can explain things loads of times. When the child doesn't know that he/ she's making a mistake, I show him/her'. Aggressive Directiveness is a way of exerting influence that is characterized by a negative attitude towards others in which hostile behavior and humiliation are used. An example is: 'Shouting is the best method of exerting obedience; when I help somebody I like to humiliate him/ her'. Due to the ongoing controversy over the influence of directiveness on a child's development (Kuczynski, 1984; Rose-Krasnor et al., 1996; Westerman, 1990), the DAiS scale was created to measure the connection between parental directiveness and the child's behavior in the Polish sample. As was already mentioned, the results demonstrated that the parents of well-behaved children (both mothers and fathers) use more Warm-hearted Directiveness. On the contrary, the parents of difficult children use more Aggressive Directiveness (Szymańska, 2009c).

The DAiS scale does not correlate with Ray's much criticized Directiveness Scale (DS) $(r=$ $0.124, p=0.338$ ), which 'was originally designed to pick out the sort of person who is prone to behave as the Nazis did - in an aggressive, domineering and destructive way towards other people' (Ray, 1984). As it can be noticed, Ray's notion of directiveness differs from Searle's notion.

The reliability of the DAiS scale was measured using Cronbach's alpha, which was .844 for Warm-hearted Directiveness and .858 for Aggressive Directiveness. Both subscales were negatively correlated $(r=-0.334, p=0.004)$. Neither Warm-hearted Directiveness $(t(60)=0.410$, $p=0.683)$ nor Aggressive Directiveness $(t(60)=0.810, p=0.276)$ was more characteristic of either men or women (Szymańska, 2015).

Scale for parental control and obedience enforcement-PAiNK. The theoretical constructs of this scale assumed that the parent may to a greater or lesser degree be a member of the child's upbringing process. In the latter case the parent may assign responsibility to the child 
for gaining knowledge on how to behave in complex social situations. A parent who assigns responsibility to the child does not teach the child socially accepted rules of behavior but assumes that the child should and will learn them by him/herself. Contrary to this style, a parent who is to a greater degree a member of the child's upbringing process teaches the child the rules and tries to convince the child about the wisdom of those rules. These two attitudes are connected with the child's social abilities (Szymańska, 2009) and these are types of control or lack of control behaviors. Stories that measure such parental behaviors create the Parental Control dimension.

The PAiNK scale comprises three scales that measure: a) obedience enforcement, b) parental control, c) lack of parental control.

The PAiNK scale is a non-typical psychometric scale because it measures constructs with the help of stories. These stories describe different difficult situations which parents have to cope with every day, such as the child's disobedience, aggressive behaviors, lie-telling, or jealousy. Each story has four possible endings and the parents have to choose the most appropriate behavior. One of the stories, which is presented below, exemplifies a difficult situation when a child is jealous: Three-year-old Chris spilled orange juice on the new sofa. When his older brother Tom found out, he was angry that Chris had gotten away with this. Tom bore a grudge because when he had stained the carpet with paints he had to wash it. He said this was unjust. He went to his room and refused to come down for supper. a) Mom asked Tom to come down for supper, but when he refused she allowed him not to eat the meal. She thought that he was right to feel upset and he had the right to work off his stress. She said that she understood his feelings (lack of parental control and lack of obedience enforcement). b) Mom went to Tom's room and tried to explain to him that Chris was very small and that he did not understand things that Tom did, so it would not be fair to punish Chris. When Tom still protested, she firmly told him to come down for supper (parental control and obedience enforcement). c) Mom went to Tom and asked him why he did not want to come down. When the outraged boy shouted, “. . . because you always let him get away with things!', she explained that Chris was just too small to wash the sofa and that justice did not depend on treating everyone the same way. But she allowed Tom to stay in his room and to work off his stress and think things over (parental control and lack of obedience enforcement). d) Mom called Tom but when he did not answer she went to his room and repeated that he must come down for supper. She added that he might be right to feel upset but she said that sometimes she is tired and makes mistakes. She insisted on his understanding and coming down for supper (lack of parental control and obedience enforcement).

Parents have to assess how appropriate each parental behavior is. Each story ends in four possible ways: when the parent teaches the rules and expects the child to be obedient; when the parent does not give the child an explanation but expects obedience; when the parent teaches the rules but does not enforce obedience and gives the child time to think it over; and, finally, when the parent neither teaches the rules nor enforces obedience.

The research participants play the role of competent judges and have to indicate the most appropriate behavior. Due to the similarity of this method to the parent's everyday difficult situations, the research participants declared that they liked the tool and found the situations familiar.

The reliability of the PAiNK scale was measured. Cronbach's alpha of the teaching rules scale was alpha $=0.628$; for obedience enforcement alpha $=0.707$. Warm-hearted directiveness and teaching rules are correlated at a low level 
$r(204)=0.221 ; p<0.05$. Aggressive Directiveness and obedience enforcement are correlated at a low level $r(204)=0.307 ; p<0.01$.

\section{Results}

\section{Methods of Statistical Analysis}

Two methods of statistical analysis were used:

- Multivariate multiple regression was used to test the level of effects of independent variables on dependent variables.

- Partial correlation and Sobel's test were used to discover the mediating and moderating effects.

Reactions to Difficult Parenting Situations Connected with the Relationship with the Child in the "Badly-Behaved"Children's Families

The study tested predictions regarding relationships among the independent variables, i.e. a) the child's age, b) child's birth order among its brothers and sisters, c) parent's education level, d) experienced difficulty, and the dependent variables, i.e. a) parental directiveness (warm-hearted or aggressive), b) parental control and c) obedience enforcement. Multivariate multiple regression was used to discover which variables shared the most common variance with the dependent variables.

Figure 2 presents a multivariate multiple regression model for the "badly-behaved" children's parents. The model fits the data well, as is indicated by the insignificant results of $C h i^{2}\left(\chi^{2}(7)=3.468, p=0.838\right)$. Experienced $\mathrm{Pa}$ rental Difficulty is only correlated with Aggressive Directiveness $\beta=0.376$. An important variable, Parental Control, is not connected with Experienced Parental Difficulty. This result means that in the group of "badly-behaved" children (who have externalizing and internalizing problems) parents who experience difficulties tend to apply Aggressive Directiveness. These parents also do not apply Parental Con-

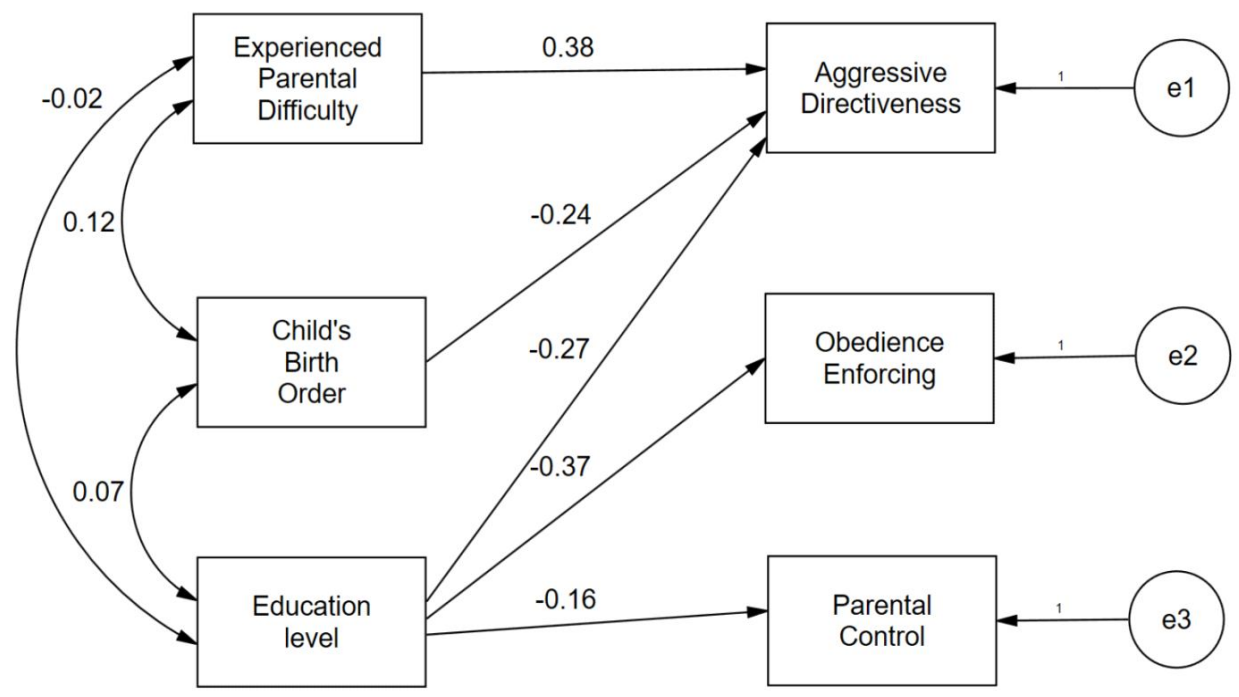

Figure 2 Multivariate multiple regression for the "badly-behaved" children's parents. $\mathrm{Chi}^{2}(7)=3.468 ; p=0.838$ 


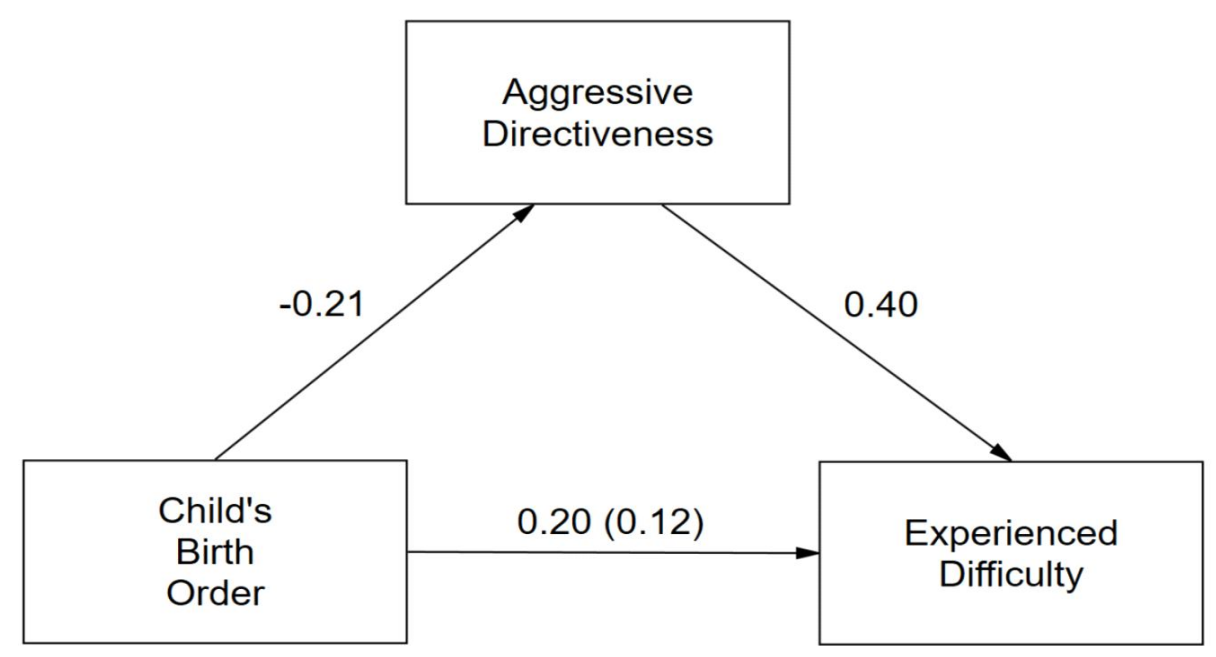

Figure 3 Regression moderation model - the "badly-behaved” children's families

trol, which in our study is understood as a method of teaching rules of social behavior to the child. In other words, these parents tend to communicate with the child in an aggressive manner (Aggressive Directiveness) and do not use explanations concerning social rules. The parents of the "badly-behaved" children use maladaptive methods of combating difficulties. They apply pressure.

Aggressive Directiveness was negatively correlated with the Parent's Education Level $\beta=$ -0.273 and Child's Birth Order $\beta=-0.237$. Warmhearted Directiveness was excluded from the model as its relationships with the independent variables were insignificant.

There is a very interesting intercorrelation between three variables: Experienced Parental Difficulty, Aggressive Directiveness and Child's Birth Order.

Child's Birth Order is negatively correlated with Aggressive Directiveness, which means that the younger the child, the less the Aggres- sive Directiveness that the parents apply (Child's Birth Order variables had higher scores for younger children: 1 - oldest, 2 - middle, 3 younger). Experienced Parental Difficulties was positively correlated both with Aggressive Directiveness (the more severe the difficulty, the more the Aggressive Directiveness the parents applied) and Child's Birth Order (the younger the child, the more difficulties the parents experienced). This result means that in these families of "badly-behaved" children the parents applied Aggressive Directiveness when they experienced difficulties but they applied it less towards younger children.

This result was checked by the regression moderation model. After adding the influence of Aggressive Directiveness, the partial correlation of Experienced Parental Difficulty and Child's Birth Order increased from $r=0.12$ (Figure 2 ) to $12 * 3=0.20$ (Figure 3 ). The significance of this effect was tested with the help of Sobel's statistic, which is used for discovering 


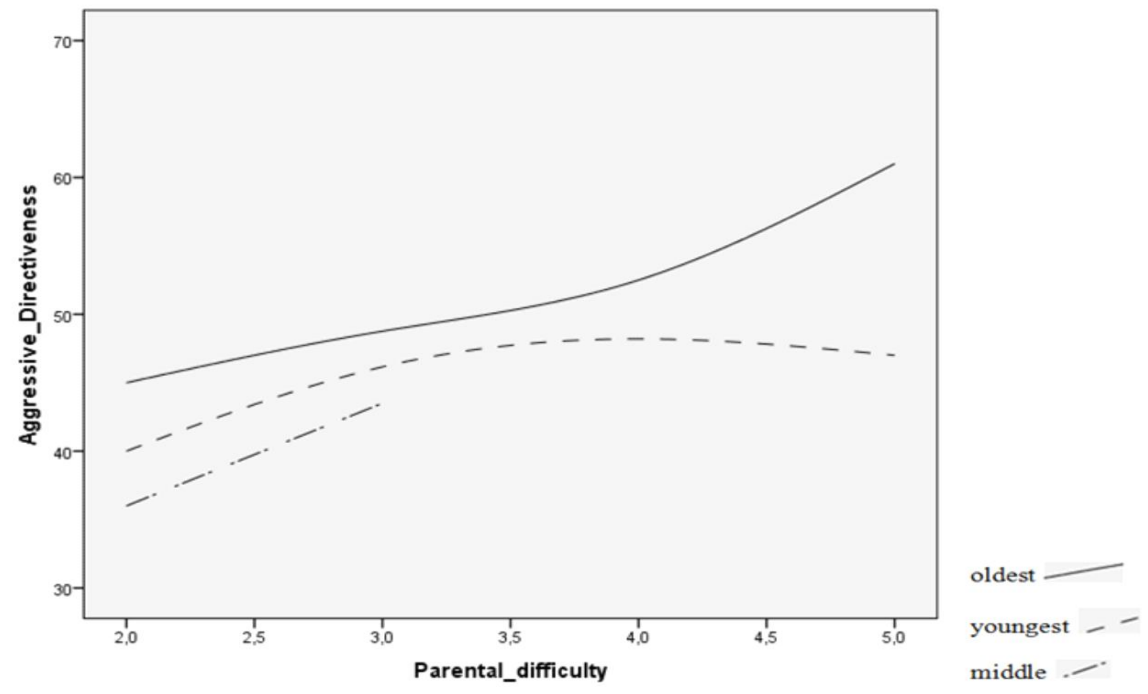

Figure 4 Interpolation lines for relations of Experienced Parental Difficulty and Aggressive Directiveness presented for each level of Child's Birth Order - the families of "badlybehaved"children

mediation effects. The effect is significant: Sobel $=-1.923, p<0.05$. Therefore, the Aggressive Directiveness that is applied by parents increases along with the experience of difficulty in the relationship with the child when the child gets older.

This result was also presented in graphical form in Figure 4. It can be observed that for the oldest children the line rises, while for the youngest children it decreases.

Reactions to Difficult Parenting Situations Connected with the Relationship with the Child in the "Well-Behaved" Children's Families

The study tested predictions regarding relationships among the independent variables, i.e. a) the child's age, b) the child's birth order, c) the parent's education level, and d) experienced parental difficulty, and the dependent variables, i.e. a) parental directiveness (warm- hearted or aggressive), b) parental control and c) obedience enforcement.

Identical analytical methods to those used for the group of "badly-behaved" children were applied.

The multivariatemultiple regression model fits the data well $\chi^{2}(5)=2.365, p=0.797$. It shows that the most important predictors of Parental Control are:Child'sBirth Order $\beta=0.313$, Experienced Parental Difficulty $\beta=0.290$, and Child's Age $\beta=$ 0.181 . The Level of Education was negatively correlated with enforcing obedience $\beta=-0.310$. The same result was achieved in the group of "badly-behaved" children. Warm-hearted Directiveness was rejected from the model as it was not correlated significantly with any other variable. This is a veryimportant result, the value of which will be discussed in the summary.

It must be noticed that the model for the "wellbehaved" children's parents differs from the model of the "badly-behaved" children's par- 
ents. The "badly-behaved" children's parents tend to apply Aggressive Directiveness when experiencing difficulties. The "well-behaved" children's parents do not apply Aggressive Directiveness nor Warm-hearted Directiveness but they do apply control. They teach their children the rules of social behavior. The parents of the "well-behaved" children apply adaptive methods of combating difficulties.

This result was also correlated with Child's Birth Order, thus it was necessary to find out whether there was a mediator.

In this group the Child's Birth Order was negatively correlated with Experienced Parental Difficulties, which means that the older the child, the more difficulties the parent experiences. Parental Control was positively correlated with both Experienced Parental Difficulty and Child's Birth Order. Therefore, the Parental control that was applied by the parents increased along with the experience of difficulty in the relationship with a child when the child got older.
This result was checked by the regression moderation model. After adding the influence of Parental Control, the partial correlation for the Child's Birth Order and Experienced Parental Difficulty increased from $r=-0.15$ (Figure 5) to $12 * 3=-0.206$ (Figure 6 ). Parental Control strengthened the connection between Child's Order and Parental Difficulty. The significance of this effect was tested with the help of Sobel's statistic: Sobel $=(2.0306), p=0.042$. The obtained result suggests that in the "well-behaved" children's families, Parental Control is the method of exerting influence in difficult situations, especially among older children. The more parents experience difficulties in their interaction with an older child, the more they apply parental control.

This result was also presented graphically in Figure 7. It can be observed that the line rises for the oldest children. When parents experience more difficulties, they apply more control on the oldest children (Figure 7).

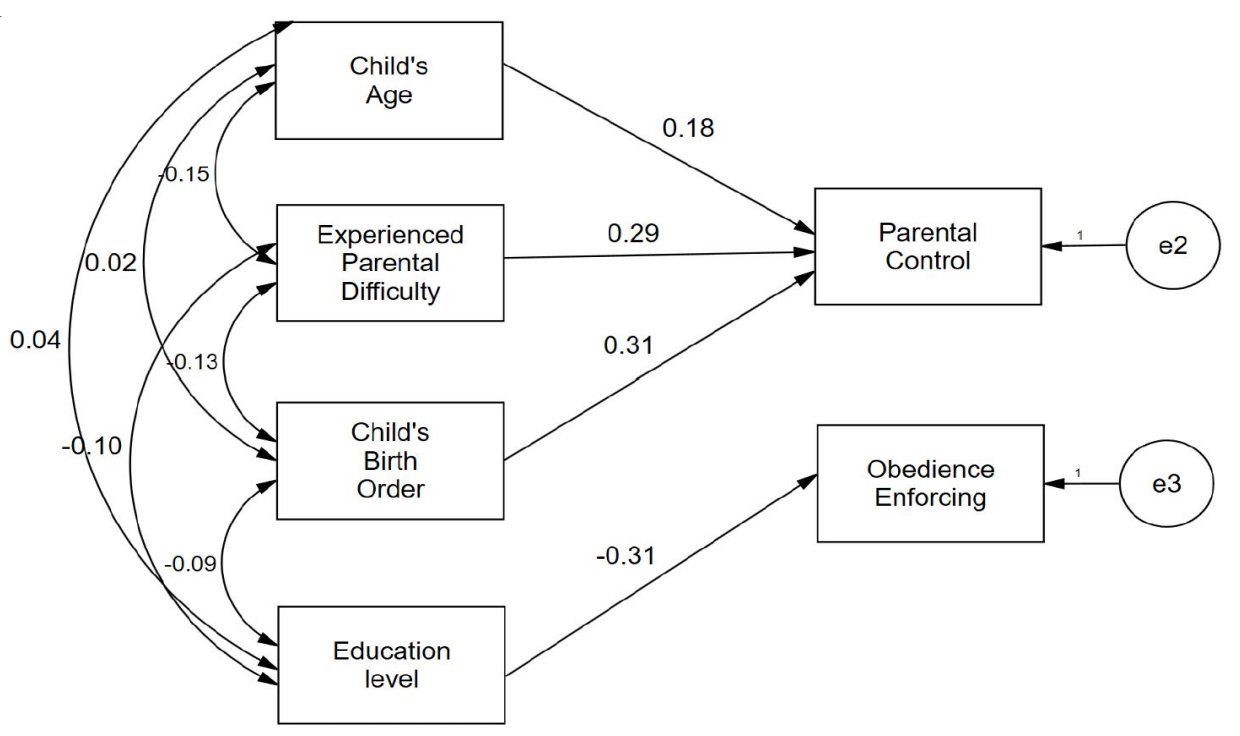

Figure 5 Multiple regression for the "well-behaved" children's parents $C h i^{2}(5)=2.365$; $p=0.797$ 


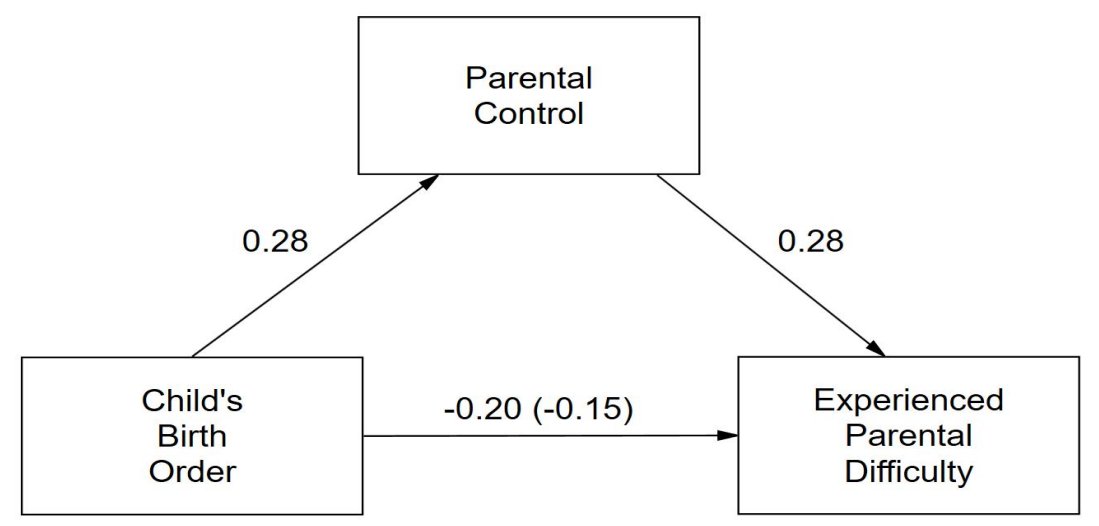

Figure 6 Regression moderation model - for well-behaved children's families

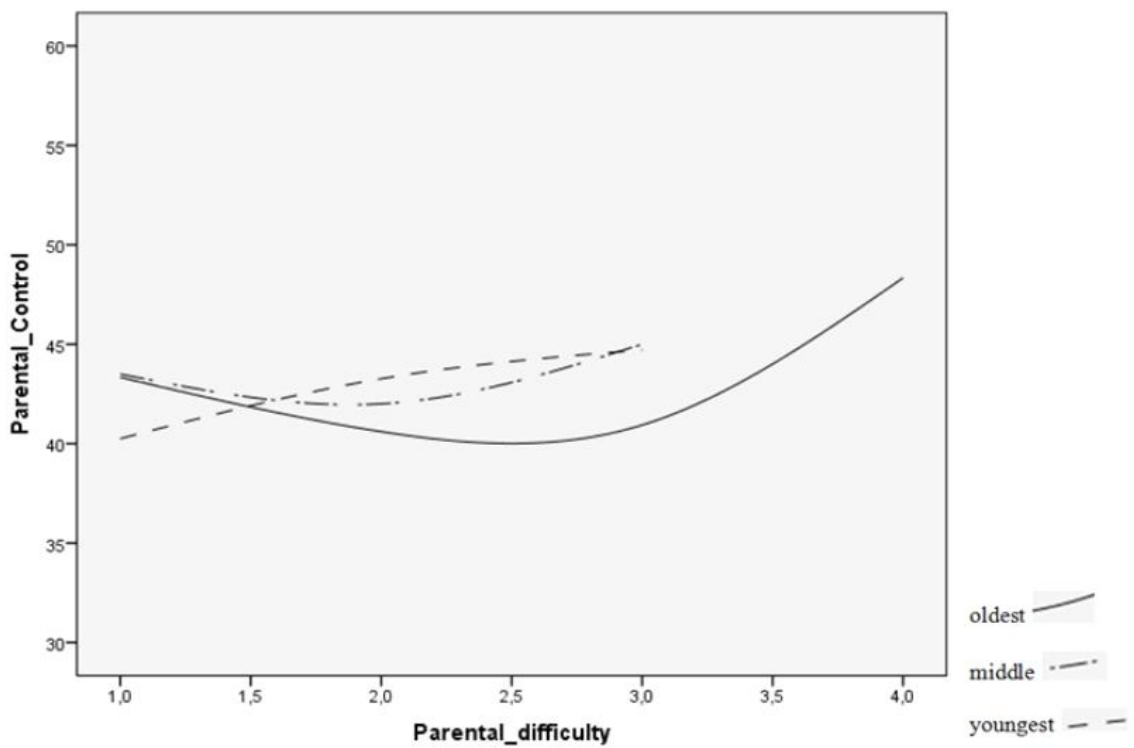

Figure 7 Interpolation lines for relations of Experienced Parental Difficulty and Parental Control presented for each level of Child's Birth Order - the families of "well-behaved"children 


\section{Discussion and Conclusion}

The results showed differences in the methods of combating stress in the groups of parents of "well-behaved" and "badly-behaved" children in parenting in difficult situations. The "badly-behaved" children's parents used Aggressive Directiveness as a method of exerting influence on their children in difficult situations, but they used this method more often on older than on younger children in families (Child's Birth Order). Aggressive Directiveness softened the effect of Child's Order and Parental Difficulty (i.e., it reduced the effect of the two other variables), thus the younger the child, the less Aggressive Directiveness the parents used, even in difficult situations. Obedience enforcement seemed to be explained not by parental difficulties but by the parent's education level, i.e. the higher the parent's education level, the less often the parent enforced obedience. As was expected, Parental Control was not connected with Experienced Difficulties in the group of "badly-behaved" children.

The results of the study indicated that the "well-behaved" children's parents used parental control as a method of exerting influence on the child in difficult situations. They used this method more often on older than on younger children in families (Child's Birth Order), which may be understood as an effort to change the child's behavior by giving explanations and teaching the rules of proper behavior. The parents of well-behaved children applied the teaching of rules as a method of exerting influence in difficult situations. They seemed to control the situation, did not lose their nerve, and used a method that had the potential of solving the problem.

On the contrary, the parents of the "badlybehaved" children had a tendency to use methods that probably only worsened the situation when they use Aggressive Directiveness. As
Bugental (Bugental, Krantz, Lyon, \& Cortez, 1997) showed in her research, parental aggressive behaviors towards the child are caused by the parent's lack of feeling that he/she can control what is happening in his/her interactions with the child. When children experience aggressive behaviors they may withdraw from their relationship with the parent (Bugental \& Happaney, 2000). Even if the parents try to explain the rules to their children but in an aggressive manner, the children's ability to assimilate these rules will be greatly impeded.

The results did not confirm the relation between Warm-hearted Directiveness and Parental Difficulty in the families of well-behaved children. This result is surprising, as Warmhearted Directiveness distinguishes the parents of well-behaved children (Szymańska, 2012b). The high score of the "well-behaved" children's parents in Warm-hearted Directiveness does not imply that these parents used this method when experiencing difficulties. This is a very interesting result of this research. It is not Warm-hearted Directiveness that is used by the parents of "well-behaved" children when they face difficulties but Parental Control and teaching the child the principles of proper behavior.

A weak point of the research was the lack of equipotence in the groups stratified according to the Child's Order. The group of middle children was particularly underrepresented. This may have resulted from the fact that this group required that the child have at least one older and one younger sibling. Unfortunately, such a group of children is difficult to find since most families in Poland have either one or two children (as a result of the demographic decline). Fortunately, the sample was quite similar for the groups of oldest and youngest children. The analyses conducted here did not require equipotence groups either.

It is also worth noting that there were more boys in the group of "badly-behaved" children. Girls are more often regarded as "well-be- 
haved". Such a distribution may also suggest that the temperament of children (boys are perceived to be more active) (Walker, Berthelsen, \& Irving, 2001) may have an impact on how the child is perceived by the teacher. However, this cannot be stated categorically as a given child's temperament was not controlled in this study. This is a limitation of this study.

Another limitation of the study was the strategy of selection of children (to groups of "wellbehaved" and "badly-behaved") according to their teachers' evaluation. Teachers can have a specific view of what constitutes "well-behaved" and "badly-behaved" children. From a teacher's point of view "well-behaved" children can be those who never cause trouble, or children who are confident, brave and joyful, willing to take part in the preschool activities. "Badly-behaved" children in teacher's opinion can be those who are shy or independent, generally children who do not fit well with teacher's strict rules. In teachers' opinion who is "wellbehaved" and who is not may be influenced by teacher's attitude to raising children. The discrepancy of views of parents and teachers could be the cause of the relatively low correlation between teacher's evaluation of children's behavior and difficulty experienced by parents.

A valuable contribution of this study is that there are significant differences between the two groups of parents with respect to the methods they use to influence difficult situations, although the small and medium correlations indicate that there may be either mediating or moderating factors that were not taken into consideration in the research.

The research presented here makes reference to the wider discussion on the influence of parental control and directiveness on a child's upbringing (Baumrind, 1966, 1983; Gaudreau et al., 2012; Goodman et al., 1999, 1999; Schaeffer, 1959; Rose-Krasnor et al., 1996; Carlson-Jones et al., 1980). These studies show that the influence of both parental control and directiveness depends on how this parental control and directiveness are applied, which is consistent with the hypotheses of Kuczynski and Westerman (Kuczynski, 1984; Westerman, 1990).

The experience that the child gains in the parenting situation when a conflict (parental difficulty) appears and whether the parent behaves aggressively or strengthens the control (teaching rules) have a non-trivial influence on the parent-child relationship as well as on the child's trust and both the parent's and child's attitudes towards each other. It seems that for the parent, his/her own way of reacting is not unrelated to his/her own representation as a competent parent (Bugental \& Happaney, 2000; Bugental, Lyon, Lin, McGrath, \& Bimbela, 1999).

The results obtained here can be interpreted in two ways. On the one hand, the aggressive directives of parents can affect the way the child behaves; on the other hand, a parent whose child creates problems may also not know how to behave differently in the face of the difficulties that he/she experiences (perhaps other interventions have proven ineffective?). Also, parental control can make children behave politely, but the well-behaved children's parents may feel that they have more influence on the child and also know how to influence the behavior of that child. These relations are bidirectional. Whether (and how) such parental reactions to difficulties influence the children's behavior is the subject of a different analysis and was not the scope of this study.

\section{References}

Baumrind, D. (1966). Effects of authoritative parental control on child behavior. Child Development, 37(4), 887-907.

Baumrind, D. (1983). Rejoinder to Lewis's reinterpretation of parental firm control effects: Are authoritative families really harmonious? Psychological Bulletin, 94(1), 132-142. 
Baumrind, D., \& Black, A. (1967). Socialization practices associated with dimensions of competence in preschool boys and girls. Child Development, 38 , 291-327.

Bruning, S., \& McMahon, C. (2009). The impact of infant crying on young women: A randomized controlled study. Journal of Reproductive and Infant Psychology, 27(2), 206-220. doi: 10.1080/ 02646830802350856

Bugental, D., \& Happaney, K. (2000). Parent-child interaction as a power contest. Journal of Applied Developmental Psychology, 21(3), 267-282.

Bugental, D., Krantz, J., Lyon, J., \& Cortez, V. (1997). Who's the boss? Differential accessibility of dominance ideation in parent-child relationship. Journal of Personality and Social Psychology, 72(6), 1297. 1309.

Bugental, D., Lyon, J., Lin, E., McGrath, E., \& Bimbela, A. (1999). Children "tuneout" in response to the ambiguous communication style of powerless adults. Child Development, 70(1), 214-230.

Bugental, D., \& Shennum, W. (1984). "Difficult" children as elicitors and targets of adult communication. Monographs of the Society for Research in Child Development, 49, 1-70.

Buss, A., \& Plomin, R. (1984). Temperament: Early developing personality traits. Hillsdale, NJ: Erlbaum.

Carlson-Jones, D., Rickel, A., \& Smith, R. (1980). Maternal child-rearing practices and social problemsolving strategies among preschoolers. Developmental Psychology, 16(3), 241-242.

Casalin, S., Tang, E., Vliegen, N., \& Luyten, P. (2014). Parental personality, stress generation, and infant temperament in emergent parent-child relationships: Evidence for a Moderated Mediation Model. Journal of Social and Clinical Psychology, 33(3), 270-291.

Casanueva, C., Goldman-Fraser, J., Ringeisen, H., Lederman, C., Katz, L., \& Osofsky, J. D. (2010). Maternal perceptions of temperament among infants and toddlers investigated for maltreatment: Implications for services need and referral. Journal of Family Violence, 25, 557-574. doi: 10.1007/ s10896-010-9316-6

Czwartosz, E. (1989). Społeczna wiedza o trudnosciach wychowawczych [Social knowledge about upbringing difficulties]. In P. J. A. Gurycka (Ed.), Podmiotowosc $w$ doswiadczeniach wychowawczych dzieci mlodziezy [Subjectivity in the educational experiences of children and young people] (pp. 161-183). Warszawa: Wydawnictwo Uniwersytetu Warszawskiego.

Del Vecchio, T., \& O’Leary, S. (2008). Predicting maternal discipline responses to early child aggression: The role of cognitions and affect. Parenting: Science and Practice, 8, 240-256.
Ebstrup, J. F., Eplov, L. F., Pisinger, C., \& Jørgensen, T. (2011). Association between the Five Factor personality traits and perceived stress: Is the effect mediated by general self-efficacy? Anxiety, Stress, \& Coping, 24(4), 407-419.

Gaudreau, P., Carraro, N., \& Miranda, D. (2012). From goal motivation to goal progress: The mediating role of coping in the Self-Concordance Model. Anxiety, Stress \& Coping, 25(5), 507-528.

Goodman, S., Bartfoot, B., Frye, A., \& Belli, A. (1999). Dimensions of marital conflictand children's social problem-solving skills. Journal of Family Psychology, 13(1), 33-45.

Guralnik, D. (1986). Webster's new world dictionary of the American language (2 ${ }^{\text {nd }}$ Edition). New York: Prentice Hall Press.

Gurycka, A. (1979). Struktura i dynamika procesu wychowawczego [Structure and dynamics of the upbringing process]. Warszawa: Wydawnictwo Naukowe PWN.

Gurycka, A. (1990). Bład w wychowaniu [Mistake in upbringing]. Warszawa: Wydawnictwa Szkolne i Pedagogiczne.

Gurycka, A. (2008). Btędy w wychowaniu [Mistakes in upbringing]. In E. Kubiak-Szymborska \& D. Zając (Eds.), O wychowaniu i jego antynomiach [On upbringing and its antinomies]. Bydgoszcz: Wydawnictwo WERS.

Katz, L. F., \& Gottman, J. M. (1993). Patterns of marital conflict predict children's internalizing and externalizing behaviors. Developmental Psychology, 29(6), 940-950. doi: 10.1037/0012-1649.29.6.940

Kochanska, G., \& Kim, S. (2013). Difficult temperament moderates links between maternal responsiveness and children's compliance and behavior problems in low-income families. The Journal of Child Psychology and Psychiatry, 3, 323-332. doi: 10.1111/ jcpp. 12002

Kowalik, S. (2011). Psychologia ucznia i nauczyciela [Psychology of pupil and teacher].Warszawa: Wydawnictwo Naukowe PWN.

Krasno, L., \& Rubin, K. (1983). Preschool social problem solving: Attempt and outcomes in naturalistic interactions. Child Development, 54(6), 1545-1558.

Kruk, E. (2005). Shared parental responsibility: A harm reduction-based approach to divorce law reform. Journal of Divorce \& Remarriage, 43, 119-140. Retrieved from http://www.tandfonline.com/doi/abs/ 10.1300/J087v43n03 07. doi: $10.1300 / J 087 v 43 n 03$

Kuczynski, L. (1984). Socialization goals and motherchild interaction: Strategies for long-term and shortterm compliance. Developmental Psychology, 20, 1061-1071.

Laukkanen, J., \& Ojansuu, U. (2014). Child's difficult temperament and mothers' parenting styles. Jour- 
nal of Child and Family Studies, 23, 312-323. doi:10.1007/s10826-013-9747-9

Lazarus, R. S., DeLongis, A., Folkman, S., \& Gruen, R. (1985). Stress and adaptational outcomes. The problem of confounded measures. The American Psychologist, 40(7), 770-785.

Lee, E. J. (2013). Differential susceptibility to the effects of child temperament on maternal warmth and responsiveness. The Journal of Genetic Psychology, 174(4), 429-449.

McLean, L. A. (2012). Child sleep problems and parental depression: Testing a Risk and Resistance Model. Journal of Child and Family Studies, 21 982-991. doi:10.1007/s10826-011-9558-9

Oddi, K. B., Murdock, K. W., \& Vadnais, S. (2013). Maternal and infant temperament characteristics as contributors to parenting stress in the first year postpartum. Infant and Child Development, 22(10), 553579.

Perkins Quamma, J., \& Greenberg, M. (1994) Children's experience of life stress: The role of family social support and social problem solving skills as protective factors. Journal of Clinical Child Psychology, 23(3), 295-397.

Pettit, G., Dodge, K., \& Brown, M. (1988). Early family experience social problem-solving pattern and children's social competence. Child Development, 59, 107-120.

Phillips, D., Crowell, N. A., Sussman, A. L., Fox, N., \& Hane, A. A. (2012). Reactive temperament and sensitivity to context in childcare. Social Development, 21(3), 628-644. doi: 10.1111/j.1467-9507.2011. 00649.x

Porębska, M. (1982). Osobowosc i jej kształtowanie sie $w$ dziecinstwie $i$ mlodosci [Personality and its development in childhood and adolescence]. Warszawa: Wydawnictwa Szkolne i Pedagogiczne.

Praszkier, R. (1992). Zmieniac nie zmieniajac: Ekologia problemów rodzinnych. Warszawa: Wydawnictwa Szkolne i Pedagogiczne.

Puura, K., Antymaa, M. M., Anen, J. L., Peltola, M., Salmelin, R., Luoma, I., Tamminen, T. (2013). Associations between maternal interaction behavior, maternal perception of infant temperament, and infant social withdrawal. Infant Mental Health Journal, 34(6), 586-594.

Ray, J. (1984). Directiveness and authoritarianism: A rejoinder to Duckitt. South African Journal of Psychology, 14(2), 64.

Ray, J., \& Lovejoy, F. (1988). An improved Directiveness Scale. Australian Journal of Psychology, 40(3), 299-302.

Reber, A., \& Reber, E. (2005). Stownik psychologii [Psychology dictionary]. Warszawa: Wydawnictwo Naukowe SCHOLAR.
Reeve, J. M. (2005). Understanding motivation and emotion. Hoboken: John Wiley \& Sons.

Reykowski, J. (1966). Funkcjonowanie osobowosci w sytuacji stresu psychologicznego [Personality functioning under psychological stress]. Warszawa: Wydawnictwo Naukowe PWN.

Rose-Krasnor, L., Rubin, K., Booth, C., \& Coplan, R. (1996). The relation of maternal directiveness and child attachment security to social competence in preschoolers. International Journal of Behavioral Development, 19(2), 309-325.

Schaeffer, E. S. (1959). A circumplex model for maternal behavior. Journal of Abnormal Social Psychology, 59, 226-235.

Searle, J. R. (1983). Intentionality: An essay in the philosophy of mind. Cambridge: Cambridge University Press.

Selye, H. (1956). The stress of life. New York: McGrawHill.

Stewart, S., \& Rubin, K. (1995). The social problem solving of anxious-withdrawn children. Development and Psychopathology, 7(2), 323-336.

Szymańska, A. (2008a). Jak rozmawiac z dzieckiem? aspekty dyrektywności rodzicielskiej. Warszawa: Paper presented at Dialog w Teorii i Praktyce Pedagogicznej, Akademia Pedagogiki Specjalnej.

Szymańska, A. (2008b). Jak wpływac na dziecko? Aspekty dyrektywnosci i kontrolirodzicielskiej. In J. Rajang, J. Lessing-Pernak (Ed.), Psychologia $w$ zyciu osobistym i zawodowym czlowieka (pp. 7889). Bydgoszcz: Instytut Psychologii, Studenckie Koła Naukowe.

Szymańska, A. (2009a). Aspekty kontroli rodzicielskiej i dyscyplinowania dziecka [Aspects of parental control and disciplining of children]. Psychologia Rozwojowa, 14(1), 37-47.

Szymańska, A. (2009b). Parental control and discipline. Vilnius, Lithuania: Paper presented at the European Conference on Developmental Psychology.

Szymańska, A. (2009c). Parental directiveness and children's social abilities. In paper presented at the International Conference on Psychology and Education. Portugal.

Szymańska, A. (2011). Błąd wychowawczy a stosowana dyrektywnosc rodzicielska. Studia Psychologica, 11(1), 99-112.

Szymańska, A. (2012a). Doswiadczana przez rodzica trudnosc w sytuacji wychowawczeja reprezentacja dziecka w umysle rodzica: Model zjawiska [Parental difficultiesencountered in upbringing situations and the child's representation in the parent's mind: A model]. Psychologia Rozwojowa, 17(4), 79-91.

Szymańska, A. (2012b). Parental directiveness as a predictor of children's behavior at kindergarten. 
Psychology of Language and Communication, 16(3), 1-24.

Szymańska, A. (2015). Psychometric report on properties of Aggressive and Warm-hearted Directiveness Scale (DAiS-R) and its application for measurement of parental communication style. Studia Psychologica, 15(2), 71-82.

Szymańska, A., Dobrenko, K., \& Grzesiuk, L. (2016). Badania nad psychoterapi. Cechy pacjenta, jego doswiadczenia z przebiegu psychoterapii a jej skutecznosc. Warszawa: Referat wygłoszony na
Konferencji Osobowosc i temperament a psychoterapia.

Walker, S., Berthelsen, D., \& Irving, K. (2001). Temperament and peer acceptance in early childhood: Sex and social status differences. Child Study Journal, 31(3), 177-192.

Westerman, M. (1990). Coordination of maternal directives with preschoolers' behaviour in compliance: Problem and healthy dyads. Developmental Psychology, 26, 621-630. 